medRxiv preprint doi: https://doi.org/10.1101/2020.05.26.20114025; this version posted May 29, 2020. The copyright holder for this preprint (which was not certified by peer review) is the author/funder, who has granted medRxiv a license to display the preprint in perpetuity.

It is made available under a CC-BY-NC-ND 4.0 International license.

\title{
Modelling the thermal inactivation of viruses from the Coronaviridae family in suspensions or on surfaces with various relative humidities.
}

\section{Authors:}

Laurent Guillier, ${ }^{a}$ Sandra Martin-Latil, ${ }^{b}$ Estelle Chaix, ${ }^{a}$ Anne Thébault, ${ }^{a}$ Nicole Pavio, ${ }^{c}$ Sophie Le Poder, ${ }^{c}$ on behalf of Covid-19 Emergency Collective Expert Appraisal Group, ${ }^{d}$ Christophe Batéjat, ${ }^{e}$ Fabrice Biot, ${ }^{f}$, Lionel Koch, ${ }^{f}$ Don Schaffner, ${ }^{g}$ Moez Sanaa, ${ }^{a}$

\section{Affiliations:}

aRisk Assessment Department, French Agency for Food, Environmental and Occupational Health \& Safety, 14, rue Pierre et Marie Curie, Maisons-Alfort, France bLaboratory for food safety French Agency for Food, Environmental and Occupational Health \& Safety, University of Paris-EST, Maisons-Alfort, France

'UMR Virologie 1161, ENVA, INRAE, Anses, Maisons-Alfort, France

dMembership of the Covid-19 Emergency Collective Expert Appraisal Group is provided in the Acknowledgments

eUnité Environnement et Risques Infectieux, Cellule d'Intervention Biologique d'Urgence (CIBU), Institut Pasteur, Paris, France

'Bacteriology Unit, French Armed Forces Biomedical Research Institute (IRBA), Brétigny-sur-Orge, France

9Department of Food Science, Rutgers University, New Brunswick, NJ, USA

\section{Affiliations:}

Running Head: Modelling the inactivation of coronaviruses on fomites 
medRxiv preprint doi: https://doi.org/10.1101/2020.05.26.20114025; this version posted May 29, 2020. The copyright holder for this preprint (which was not certified by peer review) is the author/funder, who has granted medRxiv a license to display the preprint in perpetuity.

It is made available under a CC-BY-NC-ND 4.0 International license.

\section{Abstract:}

Temperature and relative humidity are major factors determining virus inactivation in the environment. This article reviews inactivation data of coronaviruses on surfaces and in liquids from published studies and develops secondary models to predict coronaviruses inactivation as a function of temperature and relative humidity. A total of 102 D-values (time to obtain a $\log _{10}$ reduction of virus infectivity), including values for SARS-CoV-2, were collected from 26 published studies. The values obtained from the different coronaviruses and studies were found to be generally consistent. Five different models were fitted to the global dataset of D-values. The most appropriate model considered temperature and relative humidity. A spreadsheet predicting the inactivation of coronaviruses and the associated uncertainty is presented and can be used to predict virus inactivation for untested temperatures, time points or new coronavirus strains.

Importance: The prediction of the persistence of SARS-CoV-2 on fomites is essential to investigate the importance of contact transmission. This study collects available information on inactivation kinetics of coronaviruses in both solid and liquid fomites and creates a mathematical model for the impact of temperature and relative humidity on virus persistence. The predictions of the model can support more robust decision-making and could be useful in various public health contexts. Having a calculator for the natural clearance of SARS-CoV-2 depending on temperature and relative humidity could be a valuable operational tool for public authorities.

Keywords: Persistence, coronavirus, modelling, fomites, SARS-CoV-2 
medRxiv preprint doi: https://doi.org/10.1101/2020.05.26.20114025; this version posted May 29, 2020. The copyright holder for this preprint (which was not certified by peer review) is the author/funder, who has granted medRxiv a license to display the preprint in perpetuity.

It is made available under a CC-BY-NC-ND 4.0 International license .

\section{Introduction}

The pandemic of coronavirus respiratory infectious disease (COVID-19) initiated in Wuhan, China in December 2019 was caused by an emergent virus named Severe Acute Respiratory Syndrome Coronavirus 2 (SARS-CoV-2). SARS-CoV-2 belongs to the order Nidovirales, family Coronaviridae. These enveloped viruses have a positive, single-stranded RNA genome (directly translated) surrounded by a nucleocapsid protein. Coronaviruses are classified into four genera: alpha ( $\alpha \mathrm{CoV})$, beta $(\beta \mathrm{CoV})$, gamma ( $\mathrm{YCoV})$, and delta ( $(\mathrm{CoV})$. SARS-CoV-2 belongs to the Betacoronavirus genus and the Sarbecovirus sub-genus.

The route of transmission of respiratory viruses is airborne via inhalation of droplets and aerosols or through contact with contaminated intermediate objects (fomites), e.g. by self-inoculation of mucous membranes (mouth, eyes) by contaminated hands (1). The transmission route for SARS-CoV-2, SARS-CoV and Middle East respiratory syndrome (MERS-CoV) is primarily airborne (2-5) while environmental contamination through surfaces is uncertain (6-8). No study has currently quantified the importance of surface contact transmission in the spread of coronavirus diseases (9). Viral genomes have been detected in the stools of COVID-19 patients and sewage (10), but the role of liquid fomites has not yet been addressed.

Working with highly virulent coronavirus requires biosafety level 3 laboratory containment conditions and since SARS-CoV2 emerged very recently, few data on its survival related to environmental conditions are available $(11,12)$. The use of surrogate coronaviruses has been suggested to overcome these challenges and expand the available data on coronavirus survival likelihood (13). Surrogates can be used under the assumption that they have similar physicochemical properties that mimic the viruses they represent $(14,15)$. 
medRxiv preprint doi: https://doi.org/10.1101/2020.05.26.20114025; this version posted May 29, 2020. The copyright holder for this preprint (which was not certified by peer review) is the author/funder, who has granted medRxiv a license to display the preprint in perpetuity.

It is made available under a CC-BY-NC-ND 4.0 International license .

Temperature and relative humidity have been shown to impact the kinetics of inactivation of coronaviruses. Increased temperatures have been shown to increase the rate of the inactivation $(11,16)$, and decreased relative humidity have been associated with a reduction of coronaviruses inactivation rate on surfaces $(13,17)$. Inactivation rates were lower in suspensions compared to surfaces in studies that tested both suspensions and surfaces at similar temperatures $(11,18)$.

Hence, the prediction of the persistence of SARS-CoV-2 on fomites is essential to investigate the importance of contact transmission. This study collects available information on inactivation kinetics of coronaviruses in both solid and liquid fomites and models the impact of temperature and relative humidity on virus persistence.

\section{Materials \& methods}

\subsection{Selection of the studies}

Four inclusion criteria were used to identify studies that characterized inactivation of coronaviruses according to temperature and relative humidity. Selected studies had to focus on one virus from the Coronaviridae family. Inactivation must have been carried out in suspensions or on inert non-porous surfaces. Only surfaces without antimicrobial properties were considered. The quantification of infectious viruses had to be assessed by cell culture, since RT-qPCR can underestimate actual virus infectivity $(19,20)$. Finally, the available kinetics data points should be sufficient to allow precise statistical estimation of the rate of viral inactivation without bias. In this context, kinetic data with no significant inactivation observed during the experiment or with values below the quantification limit in the first time interval were not included. 
medRxiv preprint doi: https://doi.org/10.1101/2020.05.26.20114025; this version posted May 29, 2020. The copyright holder for this preprint (which was not certified by peer review) is the author/funder, who has granted medRxiv a license to display the preprint in perpetuity.

\subsection{Data collection}

The kinetics were gathered from either the figures or the tables of the selected studies. The digitize R package (21) was used to retrieve data from scatter plots in figures. This package loads a graphical file of a scatterplot (in jpeg format) in the graphical window of $\mathrm{R}$ and calibrates and extracts the data. Data were manually reported in $\mathrm{R}$ vector for data provided in tables. A key was attributed to kinetics collected in each study (Table 1). The specific list of tables and figures used for each kinetics is given in appendix 1 .

\subsection{Modelling of inactivation}

A simple primary model was used for describing each inactivation kinetics. The Dvalues (or decimal reduction times) were determined from the kinetics of the $\log _{10}$ number of infectious viruses $(M)$ over time at each experimental temperature. $D$ is the inverse of the slope of the inactivation kinetics.

$\log _{10}(N)=\log _{10}\left(N_{0}\right)-t / D \quad$ eq. (1)

Several secondary models describing the impact of temperature $(\mathrm{T})$ and relative humidity $(\mathrm{RH})$ on $D$ values were tested. The gamma concept of inactivation was used $(22,23)$. In this approach, the inactivation of a microbial population could be estimated by:

$$
\log _{10}(D)=\log _{10}\left(D_{\text {ref }}\right)-\sum \log _{10}\left(\lambda_{x i}\left(x_{i}\right)\right) \quad \text { eq. (2) }
$$

Where $\lambda_{x i}$ quantifies the influence of each environmental factors $\left(x_{i}\right.$ corresponds to temperature and relative humidity in this study) on the microbial resistance ( $\left.D_{\text {ref }}\right)$ observed in reference conditions.

Based on eq. (2), five different secondary models were established. 
medRxiv preprint doi: https://doi.org/10.1101/2020.05.26.20114025; this version posted May 29, 2020. The copyright holder for this preprint (which was not certified by peer review) is the author/funder, who has granted medRxiv a license to display the preprint in perpetuity.

It is made available under a CC-BY-NC-ND 4.0 International license.

Model \#1 is the classical Bigelow model (24). It models only the effect of temperature. The $Z T$, the increase of temperature which leads to a tenfold reduction of $D$, value was determined as the negative inverse slope of the plot of $\log _{10}(D)$ versus temperature. $z T$ is the increase of temperature which leads to a ten-fold reduction of the decimal reduction time. $T_{\text {ref }}$ is the reference temperature (set to $4^{\circ} \mathrm{C}$ in our study) and $\log _{10}\left(D_{\text {ref }}\right)$ is the $\log _{10}(D)$ at $T_{\text {ref. }}$

Model \#1

$\log _{10}\left(\lambda_{T}(T)\right)=\frac{T-T_{r e f}}{z}$ and $\log _{10}\left(\lambda_{R H}(R H)\right)=0$

Model \#2 considers the effect of temperature, however $D$ values were fitted according to temperature using a semi-log approach, derived from Mafart et al. (2001).

$\log _{10}\left(\lambda_{T}(T)\right)=\left(\frac{T-T_{r e f}}{Z_{T}}\right)^{2}$ and $\log _{10}\left(\lambda_{R H}(R H)\right)=0$

Model \#3 is similar to model \#2 but the shape parameter $n$ was estimated instead of being set to 2 .

$$
\log _{10}\left(\lambda_{T}(T)\right)=\left(\frac{T-T_{r e f}}{Z_{T}}\right)^{n} \text { and } \log _{10}\left(\lambda_{R H}(R H)\right)=0
$$

The last two models (\#4 and \#5) include the effect of relative humidity together with the effect of temperature. In model \#4, the shape parameter for temperature was set to 2 .

$\log _{10}\left(\lambda_{T}(T)\right)=\left(\frac{T-T_{r e f}}{z_{T}}\right)^{2}$ and $\log _{10}\left(\lambda_{R H}(R H)\right)=\left\{\begin{array}{cc}\frac{\mathrm{RH}}{z_{R H}} & R H<99 \% \\ 0 & R H \geq 99 \%\end{array}\right.$

In model \#5, $\mathrm{n}$ is a model parameter to be estimated. 


$$
\log _{10}\left(\lambda_{T}(T)\right)=\left(\frac{T-T_{r e f}}{z_{T}}\right)^{n} \text { and } \log _{10}\left(\lambda_{R H}(R H)\right)=\left\{\begin{array}{cc}
\frac{\mathrm{RH}}{z_{R H}} & R H<99 \% \\
0 & R H \geq 99 \%
\end{array}\right.
$$

In models \#4 and \#5, $Z_{\mathrm{RH}}$ is the increase of relative humidity, which leads to a ten-fold reduction of the decimal reduction time.

\subsection{Model's parameters estimation}

The model's parameters were fitted with nls() R function. Confidence intervals of fitted parameters were assessed by bootstrap using nlsBoot() function from nlsMicrobio R package (25). The five models were compared according to penalizedlikelihood criteria, the Aikaike information criterion (AIC) (26) and Bayesian information criterion (BIC) (27).

$$
\begin{gathered}
A I C=p \cdot \operatorname{Ln}\left(\frac{R S S}{p}\right)+2 k \\
B I C=p \cdot \operatorname{Ln}\left(\frac{R S S}{p}\right)+k \cdot \operatorname{Ln}(p)
\end{gathered}
$$

Where RSS is the residual sum of squares, $p$ is the number of experimental points and $k$ the number of parameters in the model. The lower the AIC and BIC, the better the model fits the dataset.

\subsection{Data availability}

The detailed information on the tables and figures where the data were collected are given in appendix 1. All the scripts and data used to prepare figures and tables of this manuscript are available in a Github repository (28). 
medRxiv preprint doi: https://doi.org/10.1101/2020.05.26.20114025; this version posted May 29, 2020. The copyright holder for this preprint (which was not certified by peer review) is the author/funder, who has granted medRxiv a license to display the preprint in perpetuity.

\section{Results}

\subsection{Literature review results}

Table 1 shows the detailed characteristics of the twenty-six studies that characterized inactivation of a virus from the Coronaviridae family according to temperature and or relative humidity. Some kinetics were not appropriate for characterizing inactivation rate either because the duration of the experiments was too short to observe any significant decrease of virus infectivity, or because the quantification limit was reached before the first time point (Table 1). A total of 102 estimates of D-value were collected from 25 of the 26 studies (Appendix 1). These kinetic values represent 605 individual data points. For each curve, a D-value (i.e. decimal reduction time) was estimated. The $102 \mathrm{D}$-values are given in Appendix 1. Among the 102 kinetic values, 44 are from members of the Alphacoronavirus genus including one from Canine coronavirus (CCV), two for the feline infectious peritonitis virus (FIPV), five for the porcine epidemic diarrhea virus (PEDV), 14 for the Human coronavirus 229E (HCoV229E) and 22 from the porcine transmissible gastroenteritis coronavirus (TGEV). The remaining 58 kinetics are related to the Betacoronavirus genus, including two Human coronavirus - OC43 (HCoV-OC43), two for the bovine coronavirus, 13 for the murine hepatitis virus (MHV), eight for the MERS-CoV, 22 for the SARS-CoV and 11 for the SARS-CoV-2 . 
Table 1. Characteristics of the studies that explored inactivation of infectivity of coronavirus.

\begin{tabular}{|c|c|c|c|c|c|c|c|}
\hline Virus & Genus & Sub-genus & Strain & Measurement & $\begin{array}{l}\text { Temperatures } \\
\left({ }^{\circ} \mathrm{C}\right)\end{array}$ & $\begin{array}{l}\text { Conditions associated } \\
\text { with treatment }\end{array}$ & $\begin{array}{l}\text { Study } \\
\text { reference }\end{array}$ \\
\hline $\mathrm{BCoV}$ & Betacoronavirus & Embecovirus & Strain 88 & $\begin{array}{l}\text { PFU in Human rectal } \\
\text { tumor (HRT)-18 cells }\end{array}$ & 4 & $\begin{array}{l}\text { Salad, MEM containing } \\
2 \% \text { FBS }\end{array}$ & (29) \\
\hline CCV & Alphacoronavirus & Tegacovirus & $\mathrm{I}-71$ & CRFK cells (PFU) & $60,80^{a}$ & MEM containing $2 \%$ FCS & (30) \\
\hline FIPV & Alphacoronavirus & Tegacovirus & DF2-WT & Feline kidney (NLFK) cells & 54 & Basal Medium Eagle & (31) \\
\hline FIPV & Alphacoronavirus & Tegacovirus & ATCC-990 & $\begin{array}{l}\text { Crandell Reese feline } \\
\text { kidney cell line }\end{array}$ & $4^{\mathrm{b}}, 23$ & $\begin{array}{l}\text { Dechlorinated, filtered tap } \\
\text { water }\end{array}$ & (32) \\
\hline $\mathrm{HCoV}$ & Alphacoronavirus & Duvinacovirus & $229 E$ & $\begin{array}{l}\text { Cellular infectivity in cell } \\
\text { strain (HDCS) WI38 }\end{array}$ & 33,37 & $\begin{array}{l}\text { Maintenance medium } 2 \% \\
\text { fetal calf serum }\end{array}$ & (33) \\
\hline HCoV & Alphacoronavirus & Duvinacovirus & $229 \mathrm{E}$ & $\begin{array}{l}\text { Cellular infectivity in lung } \\
\text { cell line L132 }\end{array}$ & $21^{b}$ & $\begin{array}{l}\text { PBS, Earle's minimal } \\
\text { essential medium, Earle's } \\
\text { minimal essential } \\
\text { medium to with added } \\
\text { suspended cells }\end{array}$ & (34) \\
\hline HCoV & Alphacoronavirus & Duvinacovirus & $229 E$ & $\begin{array}{l}\text { Cellular infectivity in lung } \\
\text { cell line L132 }\end{array}$ & $21^{\mathrm{b}}$ & $\begin{array}{l}\text { Aluminum, sponge, latex } \\
\text { at } 65 \% \mathrm{RH}\end{array}$ & (34) \\
\hline $\mathrm{HCoV}$ & Alphacoronavirus & Duvinacovirus & $229 E$ & CPE on MRC- 5 cells & 21 & $\begin{array}{l}\text { Teflon, PVC, Rubber, } \\
\text { Steel, Plastic }\end{array}$ & (35) \\
\hline $\mathrm{HCoV}$ & Alphacoronavirus & Duvinacovirus & $229 E$ & - & 23 & $\begin{array}{l}\text { Cell culture supernatant } \\
\text { with or without FBS (fetal } \\
\text { bovine serum) }\end{array}$ & (18) \\
\hline HCoV & Alphacoronavirus & Duvinacovirus & $229 \mathrm{E}$ & MRC- 5 cells (TCID-50) & $4^{b}, 23$ & $\begin{array}{l}\text { Dechlorinated, filtered tap } \\
\text { water }\end{array}$ & (32) \\
\hline $\mathrm{HCoV}$ & Alphacoronavirus & Duvinacovirus & $229 E$ & $\begin{array}{l}\text { Cellular infectivity in lung } \\
\text { cell line L132 }\end{array}$ & $4^{\mathrm{b}}, 22,33,37$ & $\begin{array}{l}\text { Earle's minimal essential } \\
\text { medium }\end{array}$ & (36) \\
\hline $\mathrm{HCoV}$ & Betacoronavirus & Embecovirus & OC43 & $\begin{array}{l}\text { Cellular infectivity in cell } \\
\text { strain (HDCS) WI38 }\end{array}$ & 33,37 & $\begin{array}{l}\text { Maintenance medium } 2 \% \\
\text { fetal calf serum }\end{array}$ & (33) \\
\hline $\mathrm{HCoV}$ & Betacoronavirus & Embecovirus & Oc43 & $\begin{array}{l}\text { Cellular infectivity in } \\
\text { human rectal tumor cell } \\
\text { line HRT-18 }\end{array}$ & $21^{\mathrm{b}}$ & $\begin{array}{l}\text { PBS, Earle's minimal } \\
\text { essential medium, Earle's } \\
\text { minimal essential } \\
\text { medium to with added } \\
\text { suspended cells }\end{array}$ & (34) \\
\hline
\end{tabular}




\begin{tabular}{|c|c|c|c|c|c|c|c|}
\hline $\mathrm{HCOV}$ & Betacoronavirus & Embecovirus & OC43 & $\begin{array}{l}\text { Cellular infectivity in } \\
\text { human rectal tumor cell } \\
\text { line HRT-18 }\end{array}$ & $21^{b}$ & $\begin{array}{l}\text { Aluminum, } \text { sponge }^{\mathrm{a}} \text {, } \\
\text { latex at } 65 \% \mathrm{RH}\end{array}$ & (34) \\
\hline MERS-CoV & Betacoronavirus & Sarbecovirus & FRA2 & $\begin{array}{l}\text { Cellular infectivity in Vero } \\
\text { cells (TCID-50) }\end{array}$ & $25^{b}, 56,65$ & Cell culture supernatant & (37) \\
\hline MERS-CoV & Betacoronavirus & Sarbecovirus & HCoV-EMC/2012 & $\begin{array}{l}\text { Cellular infectivity in Vero } \\
\text { cells (TCID-50) }\end{array}$ & 20,30 & $\begin{array}{l}\text { Plastic }(30 \%, 40 \% \text { or } 80 \% \\
\text { RH) }\end{array}$ & (17) \\
\hline MERS-CoV & Betacoronavirus & Sarbecovirus & HCoV-EMC/2012 & $\begin{array}{l}\text { Cellular infectivity in Vero } \\
\text { cells (TCID-50) }\end{array}$ & 20,30 & $\begin{array}{l}\text { Plastic }(30 \%, 40 \% \text { or } 80 \% \\
\text { RH) }\end{array}$ & (17) \\
\hline MHV & Betacoronavirus & Embecovirus & - & $\begin{array}{l}\text { Cellular infectivity in DBT } \\
\text { cells }\end{array}$ & $4^{b}, 25$ & Reagent-grade water & (38) \\
\hline MHV & Betacoronavirus & Embecovirus & - & $\begin{array}{l}\text { Cellular infectivity in DBT } \\
\text { cells }\end{array}$ & $4^{b}, 25$ & Lake water & (38) \\
\hline MHV & Betacoronavirus & Embecovirus & - & $\begin{array}{l}\text { Cellular infectivity in DBT } \\
\text { cells }\end{array}$ & $4^{b}, 20,40$ & $\begin{array}{l}\text { Stainless steel surface } \\
\text { with } 20 \% \text { humidity }\end{array}$ & (13) \\
\hline MHV & Betacoronavirus & Embecovirus & - & $\begin{array}{l}\text { Cellular infectivity in DBT } \\
\text { cells }\end{array}$ & $4,20,40$ & $\begin{array}{l}\text { Stainless steel surface } \\
\text { with } 50 \% \text { humidity }\end{array}$ & (13) \\
\hline MHV & Betacoronavirus & Embecovirus & - & $\begin{array}{l}\text { Cellular infectivity in DBT } \\
\text { cells }\end{array}$ & $4,20,40$ & $\begin{array}{l}\text { Stainless steel surface } \\
\text { with } 80 \% \text { humidity }\end{array}$ & (13) \\
\hline MHV & Betacoronavirus & Embecovirus & MHV-2 & $\begin{array}{l}\text { Cellular infectivity in DBT } \\
\text { cells (PFU) }\end{array}$ & $40^{\mathrm{b}}, 60,80^{\mathrm{a}}$ & MEM containing $2 \%$ FCS & (30) \\
\hline MHV & Betacoronavirus & Embecovirus & MHV-N & $\begin{array}{l}\text { Cellular infectivity in DBT } \\
\text { cells (PFU) }\end{array}$ & $40^{\mathrm{b}}, 60,80^{\mathrm{a}}$ & MEM containing $2 \%$ FCS & (30) \\
\hline MHV & Betacoronavirus & Embecovirus & A59 & Plaque assay on $L 2$ cells & $10^{b}, 25$ & Pasteurized wastewater & (39) \\
\hline PEDV & Alphacoronavirus & Pedacovirus & V215/78 & PFU on Vero cells & 50 & $\begin{array}{l}\text { Diluted medium for virus } \\
\text { replication }\end{array}$ & (40) \\
\hline PEDV & Alphacoronavirus & Pedacovirus & CV777 & Vero cells (TCID-50) & $40,44,48$ & MEM at $\mathrm{pH} 7.2$ & (41) \\
\hline PEDV & Alphacoronavirus & Pedacovirus & CV777 & Vero cells (TCID-50) & $4^{b}, 44^{b}, 48$ & Medium at $\mathrm{pH} 7.5$ & (42) \\
\hline SARS-CoV & Betacoronavirus & Sarbecovirus & FFM-1 & $\begin{array}{l}\text { Cellular infectivity in Vero } \\
\text { cells }\end{array}$ & 56 & $\begin{array}{l}\text { Cell culture supernatant } \\
\text { with or without FBS (fetal } \\
\text { bovine serum) }\end{array}$ & (18) \\
\hline SARS-CoV & Betacoronavirus & Sarbecovirus & Urbani & $\begin{array}{l}\text { Cellular infectivity in Vero } \\
\text { cells }\end{array}$ & 56,65 , and $75^{a}$ & $\begin{array}{l}\text { DMEM } \\
\text { (Dulbecco's modified } \\
\text { Eagle's medium) }\end{array}$ & (43) \\
\hline SARS-CoV & Betacoronavirus & Sarbecovirus & HKU39849 & $\begin{array}{l}\text { Cellular infectivity in FRH- } \\
\text { K4 (TCID-50) }\end{array}$ & $28,33,38$ & Plastic stored at $95 \% \mathrm{RH}$ & (44) \\
\hline
\end{tabular}




\begin{tabular}{|c|c|c|c|c|c|c|c|}
\hline SARS-CoV & Betacoronavirus & Sarbecovirus & HKU39849 & $\begin{array}{l}\text { Cellular infectivity in FRH- } \\
\text { K4 (TCID-50) }\end{array}$ & $28^{b}, 33,38$ & $\begin{array}{l}\text { Plastic stored at } 80-89 \% \\
\mathrm{RH}\end{array}$ & (44) \\
\hline SARS-CoV & Betacoronavirus & Sarbecovirus & GVU6109 & $\begin{array}{l}\text { Cellular infectivity in Vero } \\
\text { cells (TCID-50) }\end{array}$ & 20 & VTM medium & (45) \\
\hline SARS-CoV & Betacoronavirus & Sarbecovirus & GVU6109 & $\begin{array}{l}\text { Cellular infectivity in Vero } \\
\text { cells (TCID-50) }\end{array}$ & 4,20 & $\begin{array}{l}\text { Nasopharyngeal aspirate } \\
\text { (NPA), throat and nasal } \\
\text { swab } \\
\text { (TNS) or VTM medium }\end{array}$ & (45) \\
\hline SARS-CoV & Betacoronavirus & Sarbecovirus & Tor2 AY274119.3 & $\begin{array}{l}\text { Cellular infectivity in Vero } \\
\text { cells (TCID-50) }\end{array}$ & 22 & $\begin{array}{l}\text { Plastic and stainless steel } \\
\text { stored at } 40^{\circ} \mathrm{C}\end{array}$ & (12) \\
\hline SARS-CoV & Betacoronavirus & Sarbecovirus & Utah & $\begin{array}{l}\text { Cellular infectivity in Vero } \\
\text { cells (TCID-50) }\end{array}$ & 58,68 & Iscove's 4\% FCS medium & (46) \\
\hline SARS-CoV & Betacoronavirus & Sarbecovirus & Utah & $\begin{array}{l}\text { Cellular infectivity in Vero } \\
\text { cells (TCID-50) }\end{array}$ & 22 & $\begin{array}{l}\text { Glass surface store at } 10- \\
25 \% \mathrm{RH}\end{array}$ & (46) \\
\hline SARS-CoV & Betacoronavirus & Sarbecovirus & Hanoi & $\begin{array}{l}\text { Cellular infectivity in Vero } \\
\text { cells (TCID-50) }\end{array}$ & 56 & $\begin{array}{l}\text { Minimum } \\
\text { medium }\end{array}$ & (47) \\
\hline $\begin{array}{l}\text { SARS- } \\
\text { CoV2 }\end{array}$ & Betacoronavirus & Sarbecovirus & - & $\begin{array}{l}\text { Cellular infectivity in Vero } \\
\text { cells (TCID-50) }\end{array}$ & $4,22,37,56,70^{a}$ & Virus transport medium & (11) \\
\hline $\begin{array}{l}\text { SARS- } \\
\text { CoV2 }\end{array}$ & Betacoronavirus & Sarbecovirus & - & $\begin{array}{l}\text { Cellular infectivity in Vero } \\
\text { cells (TCID-50) }\end{array}$ & 22 & $\begin{array}{l}\text { Plastic and stainless steel } \\
\text { at } 65 \% \mathrm{HR}\end{array}$ & (11) \\
\hline $\begin{array}{l}\text { SARS- } \\
\text { CoV2 }\end{array}$ & Betacoronavirus & Sarbecovirus & $\begin{array}{l}\text { WA1-2020 } \\
\text { (MN985325.1) }\end{array}$ & $\begin{array}{l}\text { Cellular infectivity in Vero } \\
\text { cells (TCID-50) }\end{array}$ & 22 & $\begin{array}{l}\text { Plastic and stainless steel } \\
\text { stored at } 40^{\circ} \mathrm{C}\end{array}$ & (12) \\
\hline $\begin{array}{l}\text { SARS- } \\
\text { CoV2 }\end{array}$ & Betacoronavirus & Sarbecovirus & - & $\begin{array}{l}\text { Cellular infectivity in Vero } \\
\text { cells (TCID-50) }\end{array}$ & $56,65^{\mathrm{a}}$ & Cell culture supernatants & (48) \\
\hline $\begin{array}{l}\text { SARS- } \\
\text { CoV2 }\end{array}$ & Betacoronavirus & Sarbecovirus & - & $\begin{array}{l}\text { Cellular infectivity in Vero } \\
\text { cells (TCID-50) }\end{array}$ & $65,95^{\mathrm{a}}$ & Nasopharyngal samples & (48) \\
\hline $\begin{array}{l}\text { SARS- } \\
\text { CoV2 }\end{array}$ & Betacoronavirus & Sarbecovirus & - & $\begin{array}{l}\text { Cellular infectivity in Vero } \\
\text { cells (TCID-50) }\end{array}$ & 56 & Sera & (48) \\
\hline TGEV & Alphacoronavirus & Tegacovirus. & D52 & $\begin{array}{l}\text { Cellular infectivity in RPtg } \\
\text { cells }\end{array}$ & $\begin{array}{l}31,35,39,43,47, \\
51 \text { and } 55\end{array}$ & $\begin{array}{l}\text { In HEPES solution at } \mathrm{pH} \\
7\end{array}$ & (16) \\
\hline TGEV & Alphacoronavirus & Tegacovirus. & D52 & $\begin{array}{l}\text { Cellular infectivity in RPtg } \\
\text { cells }\end{array}$ & $\begin{array}{l}35,39,43,47 \text {, and } \\
51\end{array}$ & $\begin{array}{l}\text { In HEPES solution at } \mathrm{pH} \\
8\end{array}$ & (16) \\
\hline TGEV & Alphacoronavirus & Tegacovirus. & - & $\begin{array}{l}\text { Cellular infectivity in ST } \\
\text { cells }\end{array}$ & $4^{b}, 20,40$ & $\begin{array}{l}\text { Stainless steel surface } \\
\text { with } 20 \% \text { humidity }\end{array}$ & (13) \\
\hline TGEV & Alphacoronavirus & Tegacovirus. & - & $\begin{array}{l}\text { Cellular infectivity in ST } \\
\text { cells }\end{array}$ & $4,20,40$ & $\begin{array}{l}\text { Stainless steel surface } \\
\text { with } 50 \% \text { humidity }\end{array}$ & (13) \\
\hline
\end{tabular}




\begin{tabular}{|c|c|c|c|c|c|c|}
\hline TGEV & Alphacoronavirus & Tegacovirus. & - & $\begin{array}{l}\text { Cellular infectivity in ST } \\
\text { cells }\end{array}$ & $4,20,40$ & $\begin{array}{l}\text { Stainless steel surface } \\
\text { with } 80 \% \text { humidity }\end{array}$ \\
\hline TGEV & Alphacoronavirus & Tegacovirus. & - & $\begin{array}{l}\text { Cellular infectivity in ST } \\
\text { cells }\end{array}$ & $4^{b}, 25$ & Reagent-grade water \\
\hline TGEV & Alphacoronavirus & Tegacovirus. & - & $\begin{array}{l}\text { Cellular infectivity in ST } \\
\text { cells }\end{array}$ & $4^{b}, 25$ & Lake water \\
\hline
\end{tabular}

a not included: limit of quantification reached for the first sample time

${ }^{b}$ not included: not enough decrease observed during experimentation

- data not specified 
medRxiv preprint doi: https://doi.org/10.1101/2020.05.26.20114025; this version posted May 29, 2020. The copyright holder for this preprint (which was not certified by peer review) is the author/funder, who has granted medRxiv a license to display the preprint in perpetuity.

It is made available under a CC-BY-NC-ND 4.0 International license .

Figure 1 shows the 102 estimates of D-values, including 40 values on inert surfaces and 62 values in suspension from temperatures ranging from $4^{\circ} \mathrm{C}$ to $68^{\circ} \mathrm{C}$. Different suspensions were noted, but most were laboratory media (Table 1).

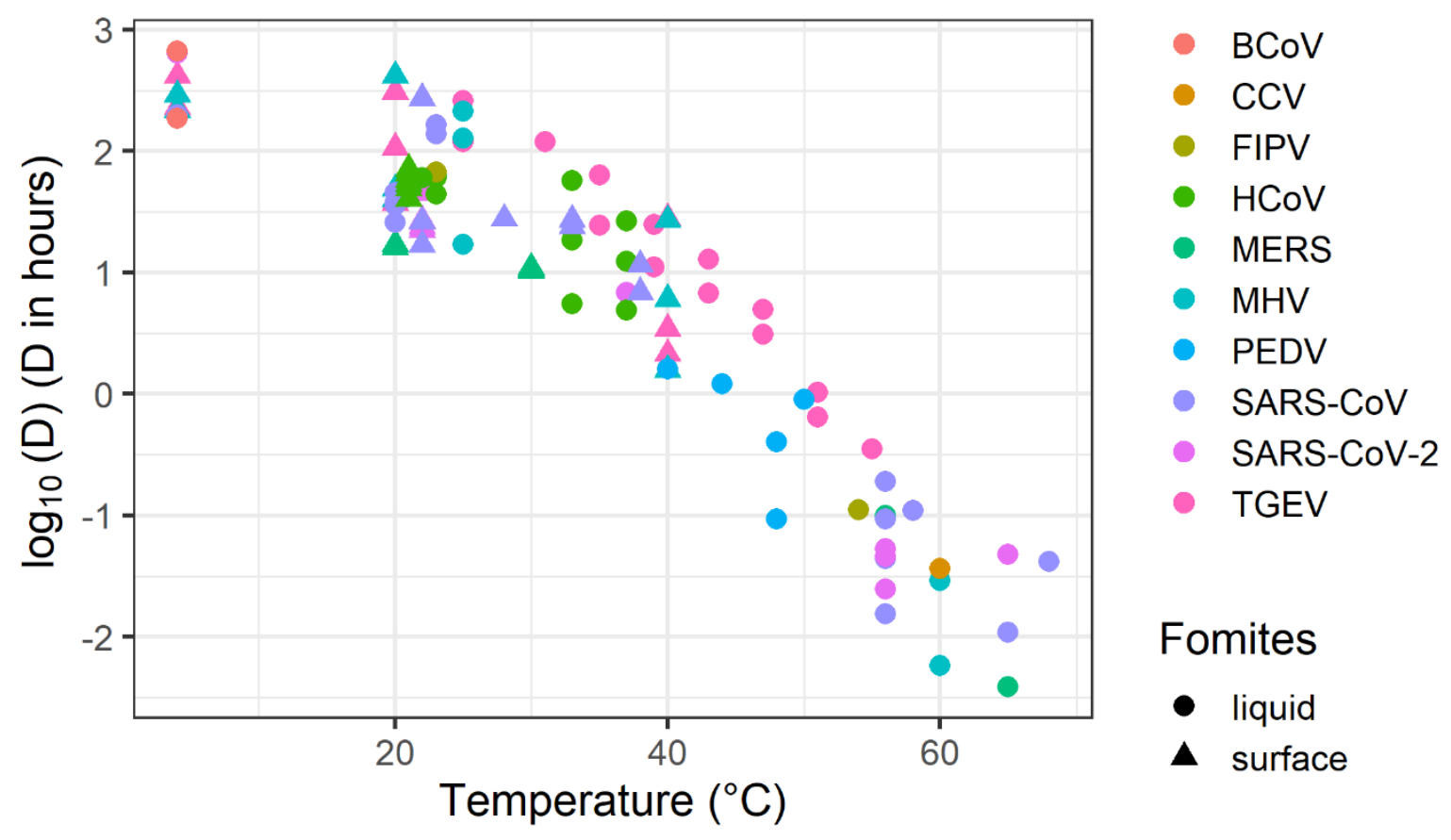

Figure 1. Decimal reduction times of ten coronaviruses according to temperature in suspension or on inert surfaces.

\subsection{Modelling the inactivation}

The $102 \mathrm{D}$-values were fitted with five different models. Table 2 shows the performance of these models to describe D-values according to temperature and relative humidity. For the tested range of temperatures (between 4 and $68^{\circ} \mathrm{C}$ ), model \#1 (the classical Bigelow model) based on a log-linear relation between D-values and temperature does not perform as well as model \#2 that considers a linear seconddegree equation. Model \#3 offers a further refinement over model \#2 by also fitting the degree of the equation ( $n$ parameter). The fitted value of $n$ was equal to 1.9 with a confidence interval that includes 2 (i.e. model \#2). Accordingly, the values taken by 
medRxiv preprint doi: https://doi.org/10.1101/2020.05.26.20114025; this version posted May 29, 2020. The copyright holder for this preprint (which was not certified by peer review) is the author/funder, who has granted medRxiv a license to display the preprint in perpetuity.

It is made available under a CC-BY-NC-ND 4.0 International license.

the parsimony criterions for model selection AIC and BIC for model \#2 and \#3, indicate that $n$ can be set to 2 .

Table 2. Characteristics of the different models fitted to the 102 decimal reduction time data of coronaviruses according to temperature $\left(T_{\text {ref }}\right.$ set at $\left.4^{\circ} \mathrm{C}\right)$ and relative humidity.

\begin{tabular}{lllll}
\hline Model & Fitted parameters & $\begin{array}{l}\text { Best fit values } \\
\text { [95\%Cl bootstrap intervals] }\end{array}$ & BIC & AIC \\
\hline Model \#1 & $\log 10$ Dref & $3.1[2.8-3.3]$ & -124.7 & -130.0 \\
& $\mathrm{Z}_{\mathrm{T}}$ & $13.8[12.7-15.1]$ & & \\
Model \#2 & $\log 10 \mathrm{Dref}$ & $2.2[2.1-2.3]$ & -160.6 & -165.9 \\
& $\mathrm{Z}_{\mathrm{T}}$ & $29.4[28.4-30.5]$ & & \\
Model \#3 & $\log 10 \mathrm{Dref}$ & $2.3[2.1-2.6]$ & -156.7 & -164.6 \\
& $\mathrm{Z}_{\mathrm{T}}$ & $27.7[23.2-31.6]$ & & \\
& $\mathrm{n}$ & $1.9[1.5-2.2]$ & & \\
Model \#4 & $\log 10 \mathrm{Dref}$ & $2.3[2.2-2.5]$ & & \\
& $\mathrm{Z}_{\mathrm{T}}$ & $29.1[28.1-30.1]$ & & \\
& $\mathrm{Z}_{\mathrm{RH}}$ & $341.4 .7[190.1-5631.4]$ & & \\
& & $2.4[2.2-2.6]$ & -168.0 \\
Model \#5 & $\log 10 \mathrm{Dref}$ & $27.5[23.6-31.2]$ & & \\
& $\mathrm{Z}_{\mathrm{T}}$ & $330.7[182.8-7020,1]$ & & \\
& $\mathrm{Z}_{\mathrm{RH}}$ & $1.9[1.6-2.2]$ & & \\
& $\mathrm{n}$ & & & \\
\hline
\end{tabular}

Figure 2 illustrates the performance of models \#1 (Fig. 2A), \#2 (Fig. 2B) and \#3 (Fig. 3C) for which only temperature effect is considered for predicting D-values. 

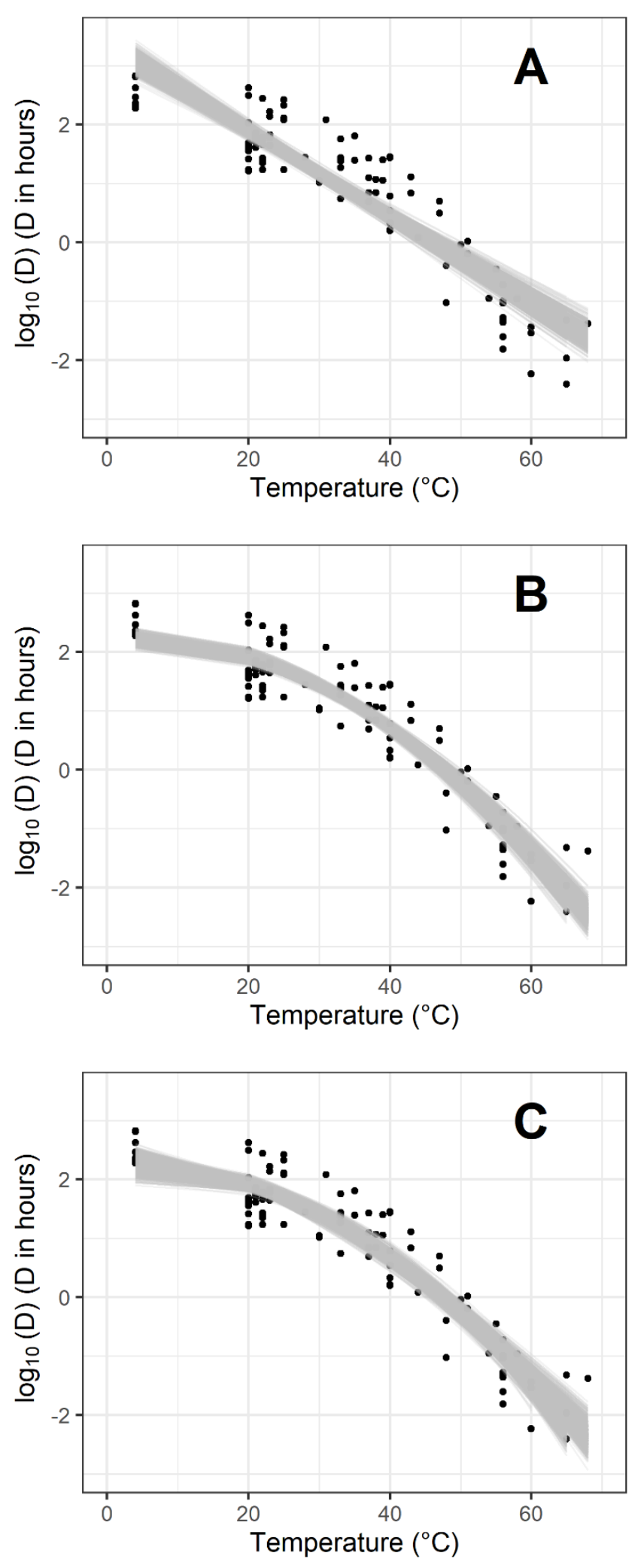

Figure 2. Observed (points) and fitted (grey lines) log decimal reduction time values according to temperature for model \#1 (A), model \#2 (B) and \#3 (C). One thousand (1000) bootstrap values of uncertainty characterisation are shown. Estimates of model parameters are given in Table 2. 
medRxiv preprint doi: https://doi.org/10.1101/2020.05.26.20114025; this version posted May 29, 2020. The copyright holder for this preprint (which was not certified by peer review) is the author/funder, who has granted medRxiv a license to display the preprint in perpetuity. It is made available under a CC-BY-NC-ND 4.0 International license .

Table 2 demonstrates that the inclusion of relative humidity should be considered.

Models \#4 and \#5 that describe the D-values according to temperature and relative humidity were more appropriate models than models \#1, \#2 and \#3 with a decrease of AIC of more than 2 points in comparison with other models (49). The estimated value for the shape parameter in Model \#5 is not different from the value two. According to BIC criterion, models \#4 and model \#2 were the most appropriate. Appendix 2 shows a further comparison of these two models. According to the two parsimony criterions, the best model overall was Model \#4. Figure 3A shows the prediction of inactivation rate according to $\mathrm{T}$ and $\mathrm{RH}$ for this model. 
medRxiv preprint doi: https://doi.org/10.1101/2020.05.26.20114025; this version posted May 29, 2020. The copyright holder for this preprint (which was not certified by peer review) is the author/funder, who has granted medRxiv a license to display the preprint in perpetuity. It is made available under a CC-BY-NC-ND 4.0 International license .

A

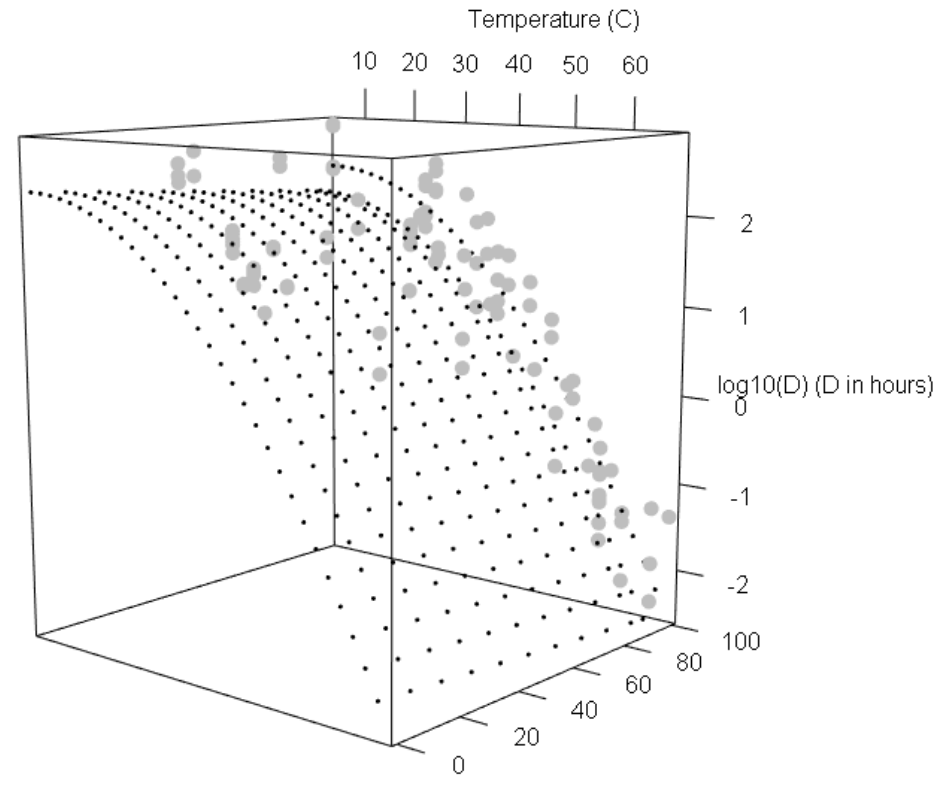

Relative Humidity (\%)

B

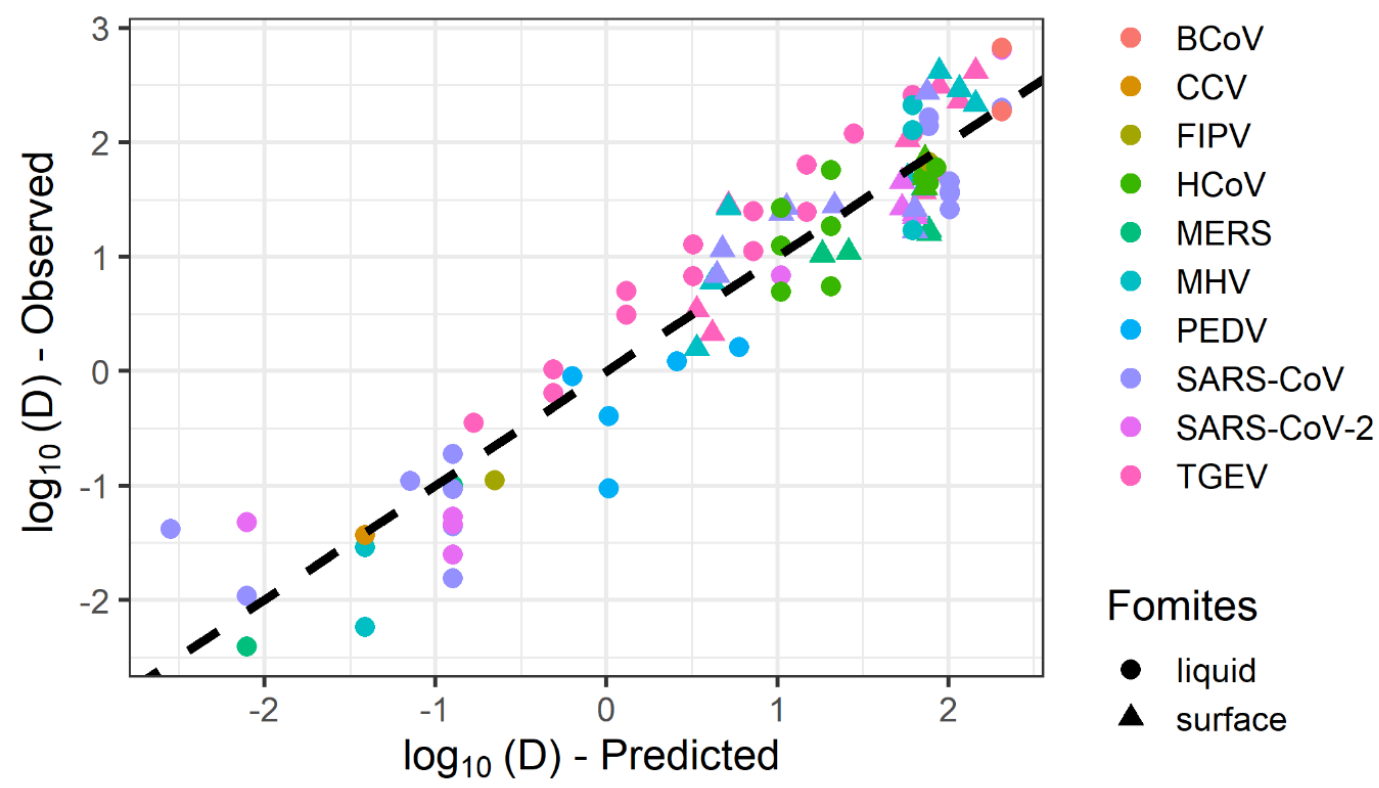

Figure 3. (A) Observed inactivation rate values (grey points) according to temperature and relative humidity and Model \#4 predictions (dashed black points). (B) Scatter points of observed versus predicted D-values. The dashed line represents a perfect match between observations and predictions. 
medRxiv preprint doi: https://doi.org/10.1101/2020.05.26.20114025; this version posted May 29, 2020. The copyright holder for this preprint (which was not certified by peer review) is the author/funder, who has granted medRxiv a license to display the preprint in perpetuity.

\subsection{Potential use of the model}

An Excel spreadsheet implementing model \#4 has been prepared and is available in Appendix 3. The spreadsheet can be used to estimate the number of decimal reductions of infectivity of coronaviruses according to user defined time, temperature and relative humidity. For example, the predicted inactivation for a temperature of $70^{\circ} \mathrm{C}$ for 1 minute in liquid is $-11.8 \log _{10}$ with a $95 \% \mathrm{Cl}[-6.4 ;-22.1]$. The spreadsheet also allows an estimate of the time necessary to reach a target number of decimal reductions of infectivity with a certain confidence level. For example, the time to reach a $5 \log _{10}$ inactivation at $20^{\circ} \mathrm{C}$ and $20 \%$ of relative humidity is $438 \mathrm{~h}$ with a $95 \%$ $\mathrm{Cl}$ of $[339 ; 569]$.

\section{Discussion}

Our study identified 102 kinetic values for inactivation of coronaviruses on surfaces and in suspensions. The included studies cover those identified in three recently published articles that conducted a systematic review on coronaviruses inactivation (50-52). These data were used to suggest a novel inactivation model specific to the Coronaviridae family. The modelling approach identified temperature and relative humidity as major factors needed to predict infectious coronavirus persistence on fomites.

The $\log _{10}$ of $D$ values was not linearly related to temperature in the range of temperatures studied $\left(4-68^{\circ} \mathrm{C}\right)$. Bertrand et al. (15) made a similar observation in a meta-analysis for virus and phage inactivation in foods and water and proposed two different models on either side of the threshold temperature of $50^{\circ} \mathrm{C}$. Laude (16) suggested a similar approach for TGEV with a threshold temperature at $45^{\circ} \mathrm{C}(16)$. 
medRxiv preprint doi: https://doi.org/10.1101/2020.05.26.20114025; this version posted May 29, 2020. The copyright holder for this preprint (which was not certified by peer review) is the author/funder, who has granted medRxiv a license to display the preprint in perpetuity.

It is made available under a CC-BY-NC-ND 4.0 International license .

The modelling approach we used in our study allows fitting the inactivation values with a single relation. In another meta-analysis on inactivation of viruses, Boehm et al. (20) did not observe such different trends but also studied a smaller temperature range $\left(4-29^{\circ} \mathrm{C}\right)$. In the highest range of temperature (above $60^{\circ} \mathrm{C}$ ), coronaviruses are found to be far less heat resistant than non-enveloped viruses (53).

The present modelling approach considers the non-monotonous impact of relative humidity on inactivation. Coronaviruses persisted better at low $\mathrm{RHs}$ and at $100 \% \mathrm{RH}$, than for intermediate RHs. Lin and Marr (54) recently observed the same relation for two bacteriophages, where the observed $\mathrm{RH}$ where survival was worst is close to $80 \%$ while in the present study, the less favourable condition for coronaviruses was set to $99 \%$. Another study has confirmed that low RH makes viruses more resistant to thermal inactivation (55).

As noted in the methods, all the kinetic values analyzed were established based on the quantification of coronavirus infectivity with cell cultures. The model prediction did not include other inactivation results from methods combining dyes with RT-qPCR. This method (although more appropriate than classical RT-qPCR) can underestimate virus infectivity $(19,20)$.

Our findings suggest that persistence potential of different coronaviruses is similar. It confirms previous finding that advocates for the use of surrogates' coronavirus such as TGEV (38). This could considerably simplify the acquisition of relevant data for persistence potential for other environmental factors. The data analyzed here only include Alpha- and Betacoronavirus, as no data for the two other major sub-genus, Delta- and Gammacoronavirus, were identified. Inclusion of such data would help to challenge the present model robustness. 
medRxiv preprint doi: https://doi.org/10.1101/2020.05.26.20114025; this version posted May 29, 2020. The copyright holder for this preprint (which was not certified by peer review) is the author/funder, who has granted medRxiv a license to display the preprint in perpetuity.

It is made available under a CC-BY-NC-ND 4.0 International license .

The models developed in our study are specific to viruses from the Coronaviridae family. Several studies on the inactivation of other viruses have suggested that the impact of temperature can be modelled, as a whole, with a unique parameter $(15,20$, 56). Variability of behavior by virus type has been observed and model parameters to account these differences have been proposed $(20,56)$, e.g. non-enveloped viruses are known to show greater persistence in the environment (56). Like a recently proposed model for SARS-CoV-2 (57), our model takes into consideration of relative humidity in the prediction of inactivation. This integration is of high interest in the perspective of assessment of seasonality on virus persistence (58).

It's also worth noting our model is specific to fomites. Survival kinetics in fecal materials were identified (45) but not considered for inclusion. The level of matrix contamination with fecal materials has been shown to significantly increase the inactivation rate of viruses (56), so by excluding these data, model predictions are biased to be fail-safe. Inactivation data on porous surfaces were also not considered since it may be difficult to determine if any measured inactivation is associated with real loss of infectivity or difficulty in recovering viruses absorbed inside the porous material. That said, there is no reason to consider that model predictions for coronaviruses are not pertinent to survival on porous material (e.g. face masks). Inactivation on anti-microbial surfaces, such as copper and silver, was also not considered. For the same reason, model predictions are fail safe as surfaces including copper or other antimicrobial compounds increase the inactivation rate of coronaviruses $(12,35)$.

The predictions of the present model could support more robust decision-making and could be useful in various contexts such as blood safety assessment (59) or validation of thermal inactivating treatments for room air, surfaces or suspensions. 
medRxiv preprint doi: https://doi.org/10.1101/2020.05.26.20114025; this version posted May 29, 2020. The copyright holder for this preprint (which was not certified by peer review) is the author/funder, who has granted medRxiv a license to display the preprint in perpetuity.

It is made available under a CC-BY-NC-ND 4.0 International license .

Indeed, an important issue is the possibility of reusing privates or public offices, rooms of hotels, or vehicles that are difficult to decontaminate. Moreover, many devices like electronics or more sensitive materials, are not suitable for chemical decontamination processes which could make them inoperative. Another aspect of decontamination is the economical challenge as large scale decontamination of buildings can cost billions of dollars (60). Furthermore, the use of detergents and/or disinfectants may have environmental consequences. Thus the large scale decontamination of surfaces for SARS-CoV-2, that are not necessarily in contact with people may not be required. For these reasons the waiting time needed before handling suspected contaminated materials in absence of decontamination is more than ever an important question. Having a calculator for the natural clearance of SARS-CoV-2 depending on temperature could be a valuable operational tool for public authorities (57).

The present model also opens the way for risk assessment for SARS-CoV-2 transmission through contact (61). Further model developments including data on matrix $\mathrm{pH}$, salinity and exposure to visible and UV light would also be important to consider (56).

\section{Acknowledgements}

The Covid-19 Emergency Collective Expert Appraisal Group members included the co-authors LG, S.M-L, E.C, N.P, S.L.P, M.S. and (in alphabetical order): Paul Brown, Charlotte Dunoyer, Florence Etore, Elissa Khamisse, Meriadeg Legouil, François Meurens, Gilles Meyer, Elodie Monchatre-Leroy, Gaëlle Simon and Astrid Vabret. 
medRxiv preprint doi: https://doi.org/10.1101/2020.05.26.20114025; this version posted May 29, 2020. The copyright holder for this preprint (which was not certified by peer review) is the author/funder, who has granted medRxiv a license to display the preprint in perpetuity.

\section{References}

1. Kutter JS, Spronken MI, Fraaij PL, Fouchier RA, Herfst S. 2018. Transmission routes of respiratory viruses among humans. Current Opinion in Virology 28:142-151.

2. Lu J, Gu J, Li K, Xu C, Su W, Lai Z, Zhou D, Yu C, Xu B, Yang Z. 2020. COVID19 Outbreak associated with air conditioning in restaurant, Guangzhou, China, 2020. Emerging Infectious Diseases 26.

3. Lee N, Hui D, Wu A, Chan P, Cameron P, Joynt GM, Ahuja A, Yung MY, Leung C, To K. 2003. A major outbreak of severe acute respiratory syndrome in Hong Kong. New England Journal of Medicine 348:1986-1994.

4. Kim S-H, Chang SY, Sung M, Park JH, Bin Kim H, Lee H, Choi J-P, Choi WS, Min J-Y. 2016. Extensive viable Middle East respiratory syndrome (MERS) coronavirus contamination in air and surrounding environment in MERS isolation wards. Reviews of Infectious Diseases 63:363-369.

5. Liu J, Liao X, Qian S, Yuan J, Wang F, Liu Y, Wang Z, Wang F, Liu L, Zhang Z. 2020. Community transmission of Severe Acute Respiratory Syndrome Coronavirus 2, Shenzhen, China, 2020. Emerging Infectious Diseases 26.

6. Chen Y-C, Huang L-M, Chan C-C, Su C-P, Chang S-C, Chang Y-Y, Chen M-L, Hung C-C, Chen W-J, Lin F-Y. 2004. SARS in hospital emergency room. Emerging Infectious Diseases 10:782.

7. Danis K, Epaulard O, Bénet T, Gaymard A, Campoy S, Bothelo-Nevers E, Bouscambert-Duchamp M, Spaccaferri G, Ader F, Mailles A, Boudalaa Z, Tolsma V, Berra J, Vaux S, Forestier E, Landelle C, Fougere E, Thabuis A, Berthelot P, Veil R, Levy-Bruhl D, Chidiac C, Lina B, Coignard B, Saura C, Team I. 2020. Cluster of coronavirus disease 2019 (Covid-19) in the French Alps, 2020. Clinical Infectious Diseases doi:10.1093/cid/ciaa424.

8. Otter JA, Donskey C, Yezli S, Douthwaite S, Goldenberg SD, Weber DJ. 2016. Transmission of SARS and MERS coronaviruses and influenza virus in healthcare settings: the possible role of dry surface contamination. Journal of Hospital Infection 92:235-250.

9. Wolff MH, Sattar SA, Adegbunrin O, Tetro J. 2005. Environmental survival and microbicide inactivation of coronaviruses, $p$ 201-212, Coronaviruses with special emphasis on first insights concerning SARS. Springer.

10. Medema G, Heijnen L, Elsinga G, Italiaander R, Brouwer A. 2020. Presence of SARS-Coronavirus-2 in sewage. medRxiv doi:https://doi.org/10.1101/2020.03.29.20045880.

11. Chin A, Chu J, Perera M, Hui K, Yen H-L, Chan M, Peiris M, Poon L. 2020. Stability of SARS-CoV-2 in different environmental conditions. . The Lancet Microbe https://doi.org/10.1016/S2666-5247(20)30003-3.

12. van Doremalen N, Bushmaker T, Morris DH, Holbrook MG, Gamble A, Williamson BN, Tamin A, Harcourt JL, Thornburg NJ, Gerber SI. 2020. Aerosol and surface stability of SARS-CoV-2 as compared with SARS-CoV-1. New England Journal of Medicine.

13. Casanova LM, Jeon S, Rutala WA, Weber DJ, Sobsey MD. 2010. Effects of air temperature and relative humidity on coronavirus survival on surfaces. Appl Environ Microbiol 76:2712-2717. 
medRxiv preprint doi: https://doi.org/10.1101/2020.05.26.20114025; this version posted May 29, 2020. The copyright holder for this preprint (which was not certified by peer review) is the author/funder, who has granted medRxiv a license to display the preprint in perpetuity.

It is made available under a CC-BY-NC-ND 4.0 International license .

14. Bozkurt H, D'Souza DH, Davidson PM. 2015. Thermal inactivation kinetics of human norovirus surrogates and hepatitis $A$ virus in turkey deli meat. Appl Environ Microbiol 81:4850-4859.

15. Bertrand I, Schijven J, Sánchez G, Wyn-Jones P, Ottoson J, Morin T, Muscillo M, Verani M, Nasser A, de Roda Husman A. 2012. The impact of temperature on the inactivation of enteric viruses in food and water: a review. Journal of Applied Microbiology 112:1059-1074.

16. Laude H. 1981. Thermal inactivation studies of a coronavirus, transmissible gastroenteritis virus. Journal of General Virology 56:235-240.

17. Van Doremalen N, Bushmaker T, Munster V. 2013. Stability of Middle East respiratory syndrome coronavirus (MERS-CoV) under different environmental conditions. Eurosurveillance 18:20590.

18. Rabenau H, Cinatl J, Morgenstern B, Bauer G, Preiser W, Doerr H. 2005. Stability and inactivation of SARS coronavirus. Medical Microbiology and Immunology 194:1-6.

19. Coudray-Meunier C, Fraisse A, Martin-Latil S, Guillier L, Perelle S. 2013. Discrimination of infectious hepatitis $A$ virus and rotavirus by combining dyes and surfactants with RT-qPCR. BMC microbiology 13:216.

20. Boehm AB, Silverman AI, Schriewer A, Goodwin K. 2019. Systematic review and meta-analysis of decay rates of waterborne mammalian viruses and coliphages in surface waters. Water research 164:114898.

21. Poisot T. 2011. The digitize package: extracting numerical data from scatterplots. The R Journal 3:25-26.

22. Coroller L, Kan-King-Yu D, Leguerinel I, Mafart P, Membré J-M. 2012. Modelling of growth, growth/no-growth interface and nonthermal inactivation areas of Listeria in foods. International Journal of Food Microbiology 152:139-152.

23. Mafart P. 2000. Taking injuries of surviving bacteria into account for optimising heat treatments. International Journal of Food Microbiology 55:175-179.

24. Bigelow W. 1921. The logarithmic nature of thermal death time curves. The Journal of Infectious Diseases:528-536.

25. Baty F, Delignette-Muller M. 2017. nlsMicrobio: data sets and nonlinear regression models dedicated to predictive microbiology. $R$ package version 0.0 1.

26. Akaike H. 1974. A new look at the statistical model identification. IEEE Transactions on Automatic Control 19:716-723.

27. Schwarz G. 1978. Estimating the dimension of a model. The Annals of Statistics 6:461-464.

28. Guillier L. 2020. Data and models related to coronaviruses inactivation. https://github.com/lguillier/Persistence-Coronavirus.

29. Mullis L, Saif LJ, Zhang Y, Zhang X, Azevedo MS. 2012. Stability of bovine coronavirus on lettuce surfaces under household refrigeration conditions. Food Microbiology 30:180-186.

30. Saknimit M, Inatsuki I, Sugiyama Y, Yagami K. 1988. Virucidal efficacy of physico-chemical treatments against coronaviruses and parvoviruses of laboratory animals. Jikken dobutsu Experimental animals 37:341.

31. Christianson K, Ingersoll J, Landon R, Pfeiffer N, Gerber J. 1989. Characterization of a temperature sensitive feline infectious peritonitis coronavirus. Archives of Virology 109:185-196.

32. Gundy PM, Gerba CP, Pepper IL. 2009. Survival of coronaviruses in water and wastewater. Food and Environmental Virology 1:10. 
medRxiv preprint doi: https://doi.org/10.1101/2020.05.26.20114025; this version posted May 29, 2020. The copyright holder for this preprint (which was not certified by peer review) is the author/funder, who has granted medRxiv a license to display the preprint in perpetuity.

33. Bucknall RA, King LM, Kapikian AZ, Chanock RM. 1972. Studies with human coronaviruses II. Some properties of strains 229E and OC43. Proceedings of the Society for Experimental Biology and Medicine 139:722-727.

34. Sizun J, Yu M, Talbot P. 2000. Survival of human coronaviruses 229E and OC43 in suspension and after drying onsurfaces: a possible source ofhospitalacquired infections. Journal of Hospital Infection 46:55-60.

35. Warnes SL, Little ZR, Keevil CW. 2015. Human coronavirus 229E remains infectious on common touch surface materials. MBio 6:e01697-15.

36. Lamarre A, Talbot PJ. 1989. Effect of $\mathrm{pH}$ and temperature on the infectivity of human coronavirus 229E. Canadian Journal of Microbiology 35:972-974.

37. Leclercq I, Batejat C, Burguière AM, Manuguerra JC. 2014. Heat inactivation of the Middle East Respiratory Syndrome coronavirus. Influenza and Other Respiratory Viruses 8:585-586.

38. Casanova L, Rutala WA, Weber DJ, Sobsey MD. 2009. Survival of surrogate coronaviruses in water. Water research 43:1893-1898.

39. Ye Y, Ellenberg RM, Graham KE, Wigginton KR. 2016. Survivability, partitioning, and recovery of enveloped viruses in untreated municipal wastewater. Environmental Science \& Technology 50:5077-5085.

40. Hofmann M, Wyler R. 1989. Quantitation, biological and physicochemical properties of cell culture-adapted porcine epidemic diarrhea coronavirus (PEDV). Veterinary Microbiology 20:131-142.

41. Quist-Rybachuk G, Nauwynck H, Kalmar I. 2015. Sensitivity of porcine epidemic diarrhea virus (PEDV) to $\mathrm{pH}$ and heat treatment in the presence or absence of porcine plasma. Veterinary microbiology 181:283-288.

42. Hulst MM, Heres L, Hakze-van der Honing R, Pelser M, Fox M, van der Poel WH. 2019. Study on inactivation of porcine epidemic diarrhoea virus, porcine sapelovirus 1 and adenovirus in the production and storage of laboratory spraydried porcine plasma. Journal of Applied Microbiology 126:1931-1943.

43. Darnell ME, Subbarao K, Feinstone SM, Taylor DR. 2004. Inactivation of the coronavirus that induces severe acute respiratory syndrome, SARS-CoV. Journal of virological methods 121:85-91.

44. Chan K, Peiris J, Lam S, Poon L, Yuen K, Seto W. 2011. The effects of temperature and relative humidity on the viability of the SARS coronavirus. Advances in Virology 2011.

45. Lai MY, Cheng PK, Lim WW. 2005. Survival of severe acute respiratory syndrome coronavirus. Clinical Infectious Diseases 41:e67-e71.

46. Pagat A-M, Seux-Goepfert R, Lutsch C, Lecouturier V, Saluzzo J-F, Kusters IC. 2007. Evaluation of SARS-Coronavirus decontamination procedures. Applied Biosafety 12:100-108.

47. Kariwa H, Fujii N, Takashima I. 2006. Inactivation of SARS coronavirus by means of povidone-iodine, physical conditions and chemical reagents. Dermatology 212:119-123.

48. Batejat C, Grassin Q, Manuguerra J-C, Leclercq I. 2020. Heat inactivation of the Severe Acute Respiratory Syndrome Coronavirus 2. bioRxiv:https://doi.org/10.1101/2020.05.01.067769.

49. Burnham KP, Anderson DR. 1998. Practical use of the information-theoretic approach, $p$ 75-117, Model selection and inference. Springer.

50. Kampf G, Voss A, Scheithauer S. 2020. Inactivation of coronaviruses by heat. Journal of Hospital Infection. 
medRxiv preprint doi: https://doi.org/10.1101/2020.05.26.20114025; this version posted May 29, 2020. The copyright holder for this preprint (which was not certified by peer review) is the author/funder, who has granted medRxiv a license to display the preprint in perpetuity. It is made available under a CC-BY-NC-ND 4.0 International license .

51. La Rosa G, Bonadonna L, Lucentini L, Kenmoe S, Suffredini E. 2020. Coronavirus in water environments: Occurrence, persistence and concentration methods-A scoping review. Water Research:115899.

52. Kampf G, Todt D, Pfaender S, Steinmann E. 2020. Persistence of coronaviruses on inanimate surfaces and its inactivation with biocidal agents. Journal of Hospital Infection.

53. Firquet S, Beaujard S, Lobert P-E, Sané F, Caloone D, Izard D, Hober D. 2014. Viruses contained in droplets applied on warmed surface are rapidly inactivated. Microbes and Environments 29:408-412.

54. Lin K, Marr LC. 2019. Humidity-Dependent Decay of Viruses, but Not Bacteria, in Aerosols and Droplets Follows Disinfection Kinetics. Environmental Science \& Technology 54:1024-1032.

55. Sauerbrei A, Wutzler P. 2009. Testing thermal resistance of viruses. Archives of virology 154:115-119.

56. Brainard J, Pond K, Hunter PR. 2017. Censored regression modeling to predict virus inactivation in wastewaters. Environmental science \& technology 51:17951801.

57. United States Department of Homeland Security. 2020. SARS-CoV-2 Indoor Environmental Stability Predictive Model. Available at: https://www.dhs.gov/sites/default/files/publications/sars-cov-

2 environment predictive model factsheet 2.pdf

58. Prussin AJ, Schwake DO, Lin K, Gallagher DL, Buttling L, Marr LC. 2018. Survival of the enveloped virus Phi6 in droplets as a function of relative humidity, absolute humidity, and temperature. Appl Environ Microbiol 84:e00551-18.

59. Chang L, Yan Y, Wang L. 2020. Coronavirus Disease 2019: Coronaviruses and Blood Safety. Transfusion Medicine Reviews doi:https://doi.org/10.1016/j.tmrv.2020.02.003.

60. Schmitt K, Zacchia NA. 2012. Total decontamination cost of the anthrax letter attacks. Biosecurity and bioterrorism: biodefense strategy, practice, and science 10:98-107.

61. Haas C. 2020. Coronavirus and Risk Analysis. Risk Analysis 40:660-661. 